\title{
The Assimilation of Glutamic Acid by Yeast
}

\author{
BY E. SHIRLEY TAYLOR \\ Medical Research Council Unit for Chemical Microbiology, Biochemical \\ Laboratory, University of Cambridge
}

SUMMARY: Using the corresponding amino-acid decarboxylases, the six amino-acids arginine, glutamic acid, histidine, lysine, ornithine and tyrosine were found to be free inside the cells of yeast. They are present when growth takes place in the absence of amino-acids, but their concentration may be increased by growing the organisms in media rich in amino-acids. Uptake of glutamic acid from the external medium is dependent on a source of energy which can be provided by the simultaneous fermentation of glucose. The presence of an ammonium salt in the medium decreases both the rate at which glutamic acid enters the cells and the amount of glutamic acid which can be taken up. Certain other amino-acids exert a similar sparing action on the assimilation of glutamic acid, which can be related to their efficiency as nitrogen sources for growth. The free glutamic acid content of cells remains practically constant when the cells are suspended in salt solutions without amino-acids, but if glucose is also present then the concentration of free glutamic acid inside the cells decreases steadily. When ammonia is also present the concentration of glutamic acid remains constant, suggesting that glutamic acid is synthesized by the cells under these conditions, or alternatively that the ammonia is assimilated and utilized preferentially.

Ehrlich $(1907,1909)$, in studies on the production of fusel-oil during yeast fermentation, showed that the organism used certain amino-acids as a source of nitrogen for growth. With a growth medium containing inorganic salts, sucrose and a single amino-acid as the sole source of nitrogen, he was able to isolate from the medium, when fermentation had ceased, either an acid or an alcohol corresponding to the amino-acid used. This result led him to suggest that yeast is able to split off carbon dioxide and ammonia from the amino-acid molecule, leaving an alcoholic residue which cannot be attacked further:

$$
R . \mathrm{CH}_{2}\left(\mathrm{NH}_{2}\right) \mathrm{COOH}+\mathrm{H}_{2} \mathrm{O} \rightarrow R . \mathrm{CH}_{2} \mathrm{OH}+\mathrm{NH}_{3}+\mathrm{CO}_{2} \text {. }
$$

From Ehrlich's work it might appear that the sole function of amino-acids in yeast nutrition is to provide a source of ammonia, which in every case is the ultimate source of nitrogen for yeast growth regardless of the amino-acid used.

These experiments were confirmed more recently by Thorne (1937), who extended them to include several amino-acids not tested by Ehrlich. Thorne has shown that all amino-acids are not equally effective as sources of nitrogen for yeast growth. Some, such as aspartic and glutamic acids, are better than ammonium phosphate, others support slower growth, and some are attacked by yeast so slowly that they are useless as sources of nitrogen for growth. Several explanations of these findings were suggested. Some of the amino-acid degradation products are inhibitors of growth and fermentation, particularly the alcohol trytophol, which is inhibitory in a concentration of $10^{-3} \mathrm{M}$ (Thorne, 1939). The production of inhibitory substances cannot be correlated with the effect on growth in all cases, however, and Thorne (1939) suggests that the 
chief reason for these differences lies in the ease with which the amino-acids can be deaminated by the yeast to liberate ammonia. Since mixtures of aminoacids are more readily attacked than would be expected from results obtained with the separate components, Thorne (1945) suggests that yeast may bring about reactions between pairs of amino-acids in a manner analogous to that found by Stickland (1934) to occur with Clostridium sporogenes.

The amino-acid decarboxylases provide a means of estimating certain aminoacids both inside the cells of micro-organisms, in the medium, or on the surface of the cells (Gale, 1947). Gale studied the passage of amino-acids, particularly glutamic acid and lysine, across the membrane of the streptococcal cell and showed that mechanisms exist whereby these amino-acids are concentrated inside the cell. He points out that this mechanism would be of greater value to organisms that are nutritionally exacting and unable to synthesize their own amino-acid requirements than to organisms that are able to do so. Stokes \& Gunness (1946) and Freeland \& Gale (1947) estimated the amino-acid composition of certain micro-organisms, including yeasts, and showed that the amino-acid composition of the cell proteins, although differing for different organisms, was unaffected by very varied growth conditions. In a survey of the ability of a wide range of organisms to assimilate amino-acids it was shown (Taylor, 1947) that the yeasts and all Gram-positive bacteria tested contained significant amounts of free amino-acids, but that no free amino-acids could be detected in the cells of Gram-negative bacteria. In the case of yeast which grows with an ammonium salt as the sole nitrogen source, and which may attack amino-acids solely in order to obtain ammonia from them, it was felt that a study of the conditions under which free amino-acids are found inside these cells might throw some further light on the problem of nitrogen assimilation by such organisms.

\section{EXPERIMENTAL}

The two organisms used for the work described in this paper were obtained from the Carlsberg collection: Yeast foam (No. 237) and Dutch Top Yeast (No. 174).

Growth of the yeasts

Medium 1. Inorganic salt medium (Stephenson, 1936) at half the strength used for bacteria; tryptic digest of casein to give final concentration equivalent to $1.5 \%$ casein; $0.2 \%(\mathrm{w} / \mathrm{v})$ Difco yeast extract; $4.0 \%(\mathrm{w} / \mathrm{v})$ glucose; $\mathrm{pH}$ adjusted to $5 \cdot 5$ before autoclaving.

Medium 2. As medium 1 but with the casein digest omitted.

Medium 3. As medium 1 but with both casein digest and Difco yeast extract omitted, and supplemented by the addition of trace elements and growth factors as follows.

(a) Growth factors (final concentration in $\mu \mathrm{g} . / \mathrm{ml}$. medium), inositol, 1.0 ; calcium pantothenate, $0 \cdot 2$; nicotinic acid, $0 \cdot 2$; pyridoxin, $0 \cdot 2$; aneurin, $0 \cdot 2$; biotin, $0 \cdot 001$.

(b) Trace elements stock solution (g./l.): $\mathrm{MgSO}_{4} \cdot 7 \mathrm{H}_{2} \mathrm{O}, 20 \cdot 0 ; \mathrm{NaCl}, 1 \cdot 0$; $\mathrm{FeSO}_{4} .7 \mathrm{H}_{2} \mathrm{O}, 0.5 ; \mathrm{ZnSO}_{4} .7 \mathrm{H}_{2} \mathrm{O}, 0.5 ; \mathrm{MnSO}_{4} .3 \mathrm{H}_{2} \mathrm{O}, 0.5 ; \mathrm{CuSO}_{4} .5 \mathrm{H}_{2} \mathrm{O}, 0.05$; 
$10 \mathrm{ml} .0 \cdot 1 \mathrm{~N}-\mathrm{H}_{2} \mathrm{SO}_{4}$. This solution was added in the proportion $10 \mathrm{ml}$./l. final medium.

The organisms were grown at $25^{\circ}$ in Roux bottles each containing $150 \mathrm{ml}$. medium.

Dry weights of the organisms in cultures and washed suspensions were estimated turbidimetrically, using a photoelectric absorptiometer previously calibrated against suspensions of the organisms of known dry weight. In the case of cultures older than $48 \mathrm{hr}$., clumped growth rendered the turbidimetric method inaccurate, and the weights were obtained by drying samples to constant weight at $100^{\circ}$.

Estimations. Amino-acids were estimated manometrically using the specific decarboxylase preparations described by Gale $(1945,1946)$. These estimate the unsubstituted L-isomers only, and consequently the amino-acids used in the assimilation experiments were the natural L-isomers in all cases, although, as shown by Nielsen \& Hartelius (1938), both D- and L-glutamic acid are completely assimilable by yeast.

Ammonia was estimated by a modification of the micro-diffusion method of Conway \& Byrne (1933). The standard acid in the centre chamber of the Conway unit was replaced by approximately $0 \cdot 1 \mathrm{~N}-\mathrm{HCl}$. When diffusion was complete, the acid was removed from the centre chamber, and transferred quantitatively with washings to a graduated cylinder, made up to a suitable volume and the ammonia estimated colorimetrically after the addition of Nessler's solution.

General procedure. The general technique used in studies on the variations in amino-acid content of the cells under various experimental conditions was as follows. The yeast, centrifuged down from the growth medium, was washed in $\mathrm{M} / 15$ potassium dihydrogen phosphate and made up into a thick suspension (20-100 mg. dry weight $/ \mathrm{ml}$.) in distilled water. The amino-acid content was assayed on a $1 \mathrm{ml}$. sample. The effect of various experimental procedures on the yeast was tested in buffered salt medium containing McIlvaine's citrate-phosphate buffer (final concentration 0.1 $\mathrm{M}$ ) and Stephenson's (1936) inorganic salt medium (ammonia-free, the ammonium phosphate being replaced by disodium hydrogen phosphate) at the concentration used in the growth media. Yeast was added to give a tenfold dilution of the thick suspension, the diluted suspension was then shaken in a constant temperature bath, and the course of the reaction followed by removing portions of the suspension at intervals and analysing both supernatant medium and cells as described below.

\section{RESULTS}

\section{Effect of varying growth conditions}

Evidence that yeasts, in common with certain Gram-positive bacteria, contain significant amounts of free amino-acids, was obtained by a modification of Gale's (1947) technique; the amino-acid present in a cell suspension is assayed before and after rupture of the cell-wall. When assaying the amino-acids outside or on the surfaces of the intact cells, it was at first found necessary to 
include manometric controls for the endogenous fermentation. It was discovered, however, that the external amino-acids are easily removed from yeast suspensions by washing, and it was therefore more convenient to eliminate fermentation controls by thorough washing of all yeast suspensions. The amount of amino-acid inside the cells can then be estimated after the cells have been ruptured by immersion of the suspension in boiling water for 20 min. Studies on the accumulation of amino-acids inside the cells of yeast were restricted to those six amino-acids which can be estimated by the decarboxylase technique.

Both yeasts (Table 1) contain all six amino-acids free in the cells, but the two organisms differ in the amounts of each amino-acid present, the most marked contrast being with lysine.

\begin{tabular}{|c|c|c|}
\hline \multicolumn{3}{|c|}{ Cells grown for $24 \mathrm{hr}$. in medium 1 . } \\
\hline \multirow{3}{*}{$\begin{array}{l}\text { L-Arginine } \\
\text { L-Glutamic acid }\end{array}$} & \multicolumn{2}{|c|}{$\begin{array}{c}\text { Yeast Foam Dutch Top Yeast } \\
(\mu \text { mol. amino-acid } / 100 \mathrm{mg} . \text { dry wt. cells })\end{array}$} \\
\hline & 4.24 & $5 \cdot 80$ \\
\hline & $10 \cdot 36$ & $17 \cdot 10$ \\
\hline L-Histidine & $\mathbf{1} \cdot 43$ & $\mathbf{2 \cdot 5 9}$ \\
\hline L-Lysine & $\mathbf{3 \cdot 8 9}$ & $42 \cdot 00$ \\
\hline L-Ornithine & $\mathbf{1 \cdot 3 0}$ & $0 \cdot 80$ \\
\hline L-Tyrosine & $0 \cdot 80$ & $3 \cdot 44$ \\
\hline
\end{tabular}

In order to determine whether the amounts of free amino-acids present varied during the course of growth, samples were taken at intervals from a large-scale culture grown in medium 1, and the results obtained with Dutch Top Yeast are shown in Fig. 1. The highest concentration of the four aminoacids tested is attained in the early stages of growth, and once growth becomes linear the content falls to a value which remains approximately constant even after growth has ceased.

In an attempt to discover whether the free amino-acids inside the cell vary in concentration according to the nature of the medium, cultures were grown in all three media. Medium $\mathbf{1}$ is rich, and medium $\mathbf{2}$ is deficient in free aminoacids, and medium 3 is free from amino-acids. Although the results (Table 2) show that the cell content is to some extent dependent on the external concentration, the yeast can still maintain a high concentration of certain aminoacids when grown in a medium where ammonia is the sole nitrogen source.

\section{Loss of amino-acids from the cells}

When yeast has been grown in medium 1 and has a high internal concentration of certain amino-acids, it seems likely that outward diffusion of those amino-acids might occur if the cells were resuspended in a medium free from amino-acids. To test this, a washed suspension of the yeast was assayed for arginine, glutamic acid and tyrosine and then added to 9 vol. of salt medium, as previously described. The dilute suspension was shaken in a constant temperature bath at $25^{\circ}$; portions were removed at intervals, the cells centri- 
fuged down, and made up into a thick washed suspension again for assay. There was no significant loss of free amino-acids from the cells during $6 \mathrm{hr}$. When, however, glucose was added as a source of fermentable carbohydrate, the amino-acid content of the cells diminished (Table 3 ).

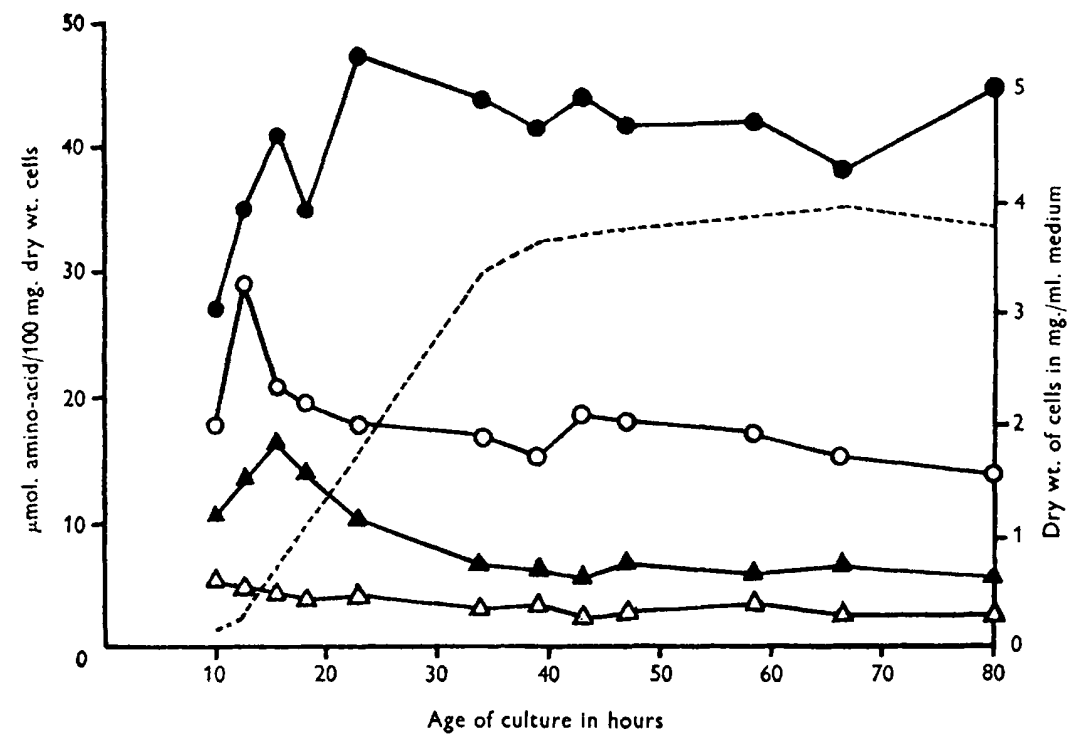

Fig. 1. Effect of age of culture on the free amino-acid content of Dutch Top Yeast. Dutch Top Yeast grown in medium 1 at $25^{\circ}$. Samples withdrawn at intervals from large-scale culture, growth estimated turbidimetrically and cells then centrifuged down. Aminoacid content of cells estimated and results expressed as $\mu \mathrm{mol}$. of free amino-acid inside $100 \mathrm{mg}$. dry wt. of cells. ......., growth of yeast; -0-0-0-, lysine; $-0.0-0-$, glutamic acid; $-\Delta-\Delta-\Delta-$, arginine; $-\triangle-\triangle-\triangle-$, tyrosine.

Table 2. Variation in free amino-acid content of Dutch Top Yeast with the nature of the growth medium

Age of culture $24 \mathrm{hr}$.

\begin{tabular}{|c|c|c|c|}
\hline \multirow[b]{3}{*}{ Amino-acid } & \multicolumn{3}{|c|}{ Age of culture $24 \mathrm{hr}$. } \\
\hline & \multicolumn{3}{|c|}{ Growth on } \\
\hline & $\begin{array}{l}\text { Medium } 1 \\
\quad(\mu \mathrm{mol} .\end{array}$ & $\begin{array}{l}\text { Medium } \\
\text { cid } / 100 \mathrm{~m}\end{array}$ & $\begin{array}{l}\text { Medium } 3 \\
\text { wt. cells) }\end{array}$ \\
\hline L-Arginine & $11 \cdot 80$ & $2 \cdot 37$ & $1 \cdot 38$ \\
\hline L-Glutamic acid & $18 \cdot 00$ & $8 \cdot 35$ & $3 \cdot 57$ \\
\hline L-Histidine & $2 \cdot 77$ & $2 \cdot 19$ & 0.58 \\
\hline L-Lysine & $46 \cdot 80$ & $2 \cdot 86$ & $0 \cdot 89$ \\
\hline L-Ornithine & $7 \cdot 14$ & 0.54 & $0 \cdot 63$ \\
\hline L-Tyrosine & $4 \cdot 02$ & $3 \cdot 57$ & $\mathbf{1} \cdot \mathbf{3 4}$ \\
\hline
\end{tabular}

The disappearance of free amino-acids from the cells might occur in a number of ways. It is possible that (i) the amino-acids are able to diffuse out of the cells when fermentation is taking place simultaneously; (ii) the amino-acids are broken down inside the cell to provide ammonia for protein synthesis; (iii) amino-acids are metabolized inside the cell in other ways, such as transamination and direct synthesis into peptides and proteins. These possibilities were investigated in the case of glutamic acid in the following way. 
The experiment described above was repeated under exactly similar conditions and glutamic acid estimated at each stage, both before (free amino-acid) and after(total amino-acid) acid hydrolysis of the sample. Although the free glutamic acid again decreased, the values obtained for the total (free + combined) glutamic acid showed that no change had occurred in the amount of combined glutamic acid during the whole course of the experiment. Disappearance of glutamic acid cannot therefore be accounted for by its being built up into peptide or protein.

Table 3. Loss of amino-acids from the cells of Dutch Top Yeast

Yeast grown for $24 \mathrm{hr}$. in medium 1 and crop incubated at $25^{\circ}$ in buffered salt mixture at $\mathrm{pH} 5.0(a)$ with and $(b)$ without glucose. Yeast suspension $6.0 \mathrm{mg}$. dry wt. $/ \mathrm{ml}$.

Amino-acid content of cells

\begin{tabular}{|c|c|c|c|c|c|c|}
\hline \multirow{3}{*}{$\begin{array}{l}\text { Time } \\
\text { (hr.) }\end{array}$} & \multicolumn{3}{|c|}{ Glucose absent } & \multicolumn{3}{|c|}{ Glucose present } \\
\hline & Arginine & $\begin{array}{l}\text { Glutamic } \\
\text { acid }\end{array}$ & Tyrosine & Arginine & $\begin{array}{l}\text { Glutamic } \\
\text { acid }\end{array}$ & Tyrosine \\
\hline & \multicolumn{6}{|c|}{ ( $\mu \mathrm{mol}$. amino-acid $/ 100 \mathrm{mg}$. dry wt. of cells) } \\
\hline 0 & $12 \cdot 25$ & $18 \cdot 75$ & $3 \cdot 62$ & $5 \cdot 80$ & $17 \cdot 15$ & $3 \cdot 44$ \\
\hline$\frac{1}{2}$ & - & - & - & 3.97 & 14.88 & $2 \cdot 82$ \\
\hline 1 & $11 \cdot 61$ & $18 \cdot 15$ & $3 \cdot 39$ & $3 \cdot 26$ & $8 \cdot 63$ & $1 \cdot 03$ \\
\hline 2 & $11 \cdot 52$ & $18 \cdot 30$ & $3 \cdot 26$ & $1 \cdot 88$ & $3 \cdot 44$ & $0 \cdot 76$ \\
\hline $\mathbf{3}$ & - & 一 & - & $0 \cdot 98$ & $1 \cdot 68$ & $0 \cdot 31$ \\
\hline 4 & $11 \cdot 80$ & $18 \cdot 40$ & $3 \cdot 53$ & - & - & - \\
\hline 6 & $11 \cdot 92$ & $19 \cdot 15$ & $3 \cdot 13$ & - & - & - \\
\hline
\end{tabular}

To test the possibility of outward diffusion of the amino-acid, the test sample was centrifuged, and the supernatant and washings concentrated by vacuum distillation and assayed for glutamic acid. The results obtained were again negative, showing that loss of glutamic acid could not be accounted for by outward diffusion. The possibility that glutamic acid is deaminated to provide ammonia was tested by estimating succinic acid, the degradation product found by Erhlich (1909) and Thorne (1937), but the amount of succinic acid formed was independent of the amount of glutamate disappearing, and could be fully accounted for as being produced from glucose. No free ammonia could be detected at any stage.

The disappearance of glutamic acid from the yẹast cell in the presence of glucose therefore appears to be the result of some internal metabolism, the nature of which is as yet obscure, but which probably consists of conversion into other amino-acids. Failure to detect succinic acid and free ammonia does not necessarily rule out the possibility of deamination, since breakdown may proceed only as far as $\alpha$-ketoglutaric acid and ammonia, both of which would enter into other reactions in the cell.

\section{Conditions affecting glutamic acid assimilation}

Presence of glucose. To investigate the conditions under which glutamic acid is assimilated by yeast, a washed suspension from a culture grown in medium 1 was assayed for internal glutamic acid and then incubated under the usual 
conditions in the presence of $0.01 \mathrm{~m}$ glutamic acid both with and without the addition of glucose. In the presence of glucose the level of glutamic acid inside the cells increased steadily, but only a comparatively small increase occurred when glucose was omitted (Table 4). This small increase may have been brought about by glucose carried over from the growth medium or by the utilization of carbohydrate reserves by the cells; it was eliminated by subjecting the yeast suspension in salt medium to vigorous aeration for $4 \mathrm{hr}$. before incubation with glutamic acid.

\section{Table 4. Effect of the presence of glucose on the uptake of glutamic acid by yeast}

Cells (24 hr. culture) incubated in buffered salt medium with or without glucose $(2 \%(w / v))$. Yeast suspension $9.0 \mathrm{mg}$. dry wt. $\mathrm{ml}$. Samples withdrawn at times shown, cells centrifuged down, washed, and internal concentration of free glutamic acid estimated. Results expressed as the change in free glutamic acid content-i.e. disappearance of free glutamic acid from the cells indicated by negative sign.

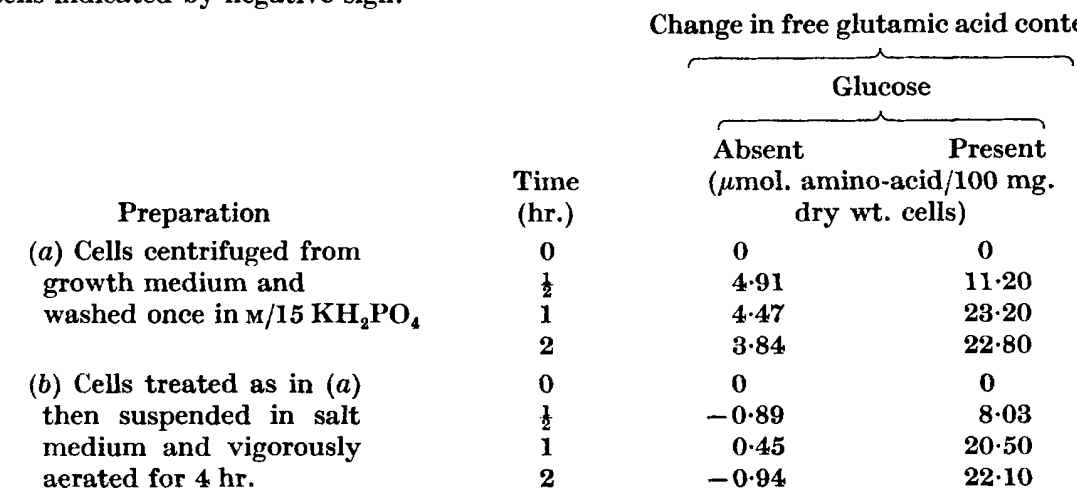

$\mathrm{pH}$ of medium. The $\mathrm{pH}$ of the suspending medium has no marked effect on the rate at which external supplies of glutamic acid can be assimilated. The $\mathrm{pH}$ curve for glucose fermentation by this organism is flat over the range $\mathrm{pH} 3 \cdot 5-6 \cdot 0$, and the rate at which glutamic acid is assimilated is optimal at $\mathrm{pH} 4.5$.

Age of culture. Since the amount of free glutamic acid inside the cells varies with the age of culture, it seemed likely that cultures of different ages would assimilate glutamic acid at different rates. Table 5 shows the results obtained when the capacity of a large-scale culture to assimilate glutamic acid was tested under standard conditions after 12, 24 and $48 \mathrm{hr}$. growth. Cells from a young culture take up glutamic acid more rapidly from the medium, and concentrate it internally to a higher degree at equilibrium than old cells do.

External concentration of glutamic acid. The effect of varying external concentrations of glutamic acid on the level attained inside the cell is shown in Fig. 2. In the presence of $0.01 \mathrm{~m}$ glutamic acid, the concentration inside the cell reached a steady value after incubation for $1 \mathrm{hr}$. At lower external concentrations, the rate at which glutamic acid is metabolized inside the cell is presumably greater than the rate at which it can be assimilated from the medium, and the internal concentration diminishes. 
Presence of an ammonium salt. When yeast cells are incubated in glutamic acid solution, the amount which disappears from the external medium is equal

\section{Table 5. Variation with age of culture in the ability of yeast cells to assimilate glutamic acid}

Cells from cultures of different ages were incubated in salts-buffer-glucose mixture containing $8.94 \mu \mathrm{mol} . / \mathrm{ml}$. glutamic acid. Yeast suspension $10.5 \mathrm{mg}$. dry wt. $/ \mathrm{ml}$. Samples were removed at times shown, the cells centrifuged down and the amino-acid content of the supernatant estimated.

\section{Duration of exposure of cells to medium (min.)}

\section{0}

15

30

60

120

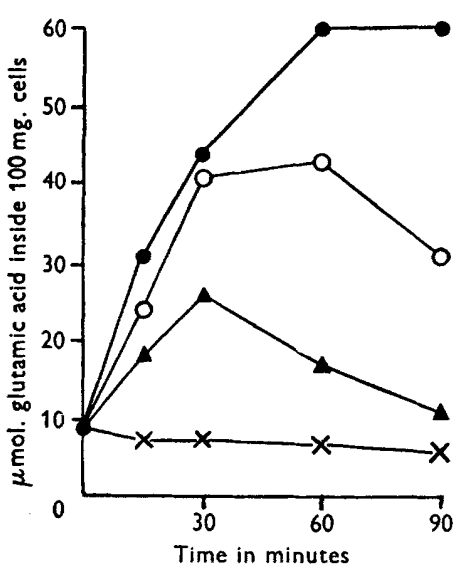

Fig. 2

\section{Age of culture supplying cells (hr.)}

$\overbrace{12}^{24} 48$

$\mu$ mol. glutamic acid taken up/100 mg. dry wt. of cells

$\quad 0$
$18 \cdot 35$
$32 \cdot 3$
$40 \cdot 5$
$42 \cdot 5$

$\begin{array}{rc}0 & 0 \\ 11 \cdot 9 & 2 \cdot 23 \\ 26 \cdot 1 & 11 \cdot 92 \\ 36 \cdot 0 & 31 \cdot 8 \\ 36 \cdot 8 & 32 \cdot 2\end{array}$

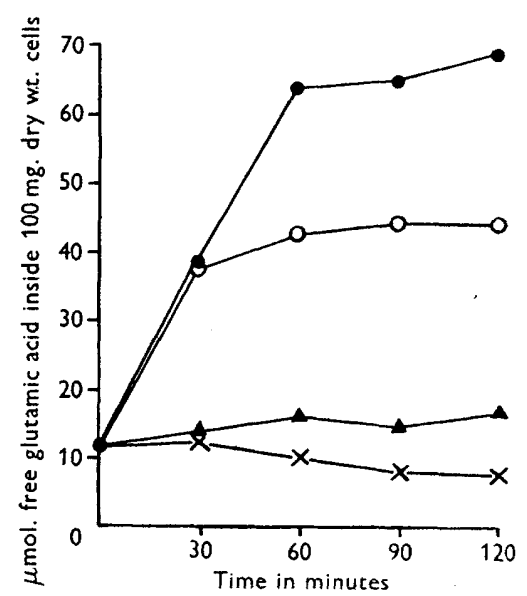

Fig. 3

Fig. 2. Effect of varying external concentrations of glutamic acid upon the glutamic acid content of yeast cells. Dutch Top Yeast grown for $24 \mathrm{hr}$. in medium 1. Cells incubated in salts-buffer-glucose mixture in the presence of varying external concentrations of glutamic acid. Temperature $25^{\circ}$. Yeast dry weight $6 \cdot 0 \mathrm{mg} . / \mathrm{ml}$. External medium: - - - - -, 8.93 $\mu \mathrm{mol}$. glutamic acid $/ \mathrm{ml}$; - - - $-\bigcirc-, 4.46 \mu \mathrm{mol}$. glutamic acid $/ \mathrm{ml}$; -A-A-A-, 2-23 $\mu \mathrm{mol}$. glutamic acid $/ \mathrm{ml}$.; - $x-x-x-$, no external glutamic acid. Results expressed as $\mu \mathrm{mol}$. free glutamic acid inside $100 \mathrm{mg}$. dry wt. of cells.

Fig. 3. Effect of the presence of ammonia on the internal metabolism of glutamic acid and on the rate of glutamic acid uptake from the external medium. Dutch Top Yeast grown for $24 \mathrm{hr}$, at $25^{\circ}$ in medium 1 . Washed suspension of cells incubated in buffered salt medium at $\mathrm{pH} 4.5$ containing $3 \%(\mathrm{w} / \mathrm{v})$ glucose and $3.7 \mathrm{mg}$. dry wt. yeast $/ \mathrm{ml}$. Ammonia concentration $14.28 \mu \mathrm{mol}$. $\mathrm{NH}_{3}-\mathrm{N} / \mathrm{ml}$. Glutamic acid concentration $8.98 \mu \mathrm{mol} . / \mathrm{ml}$. Results are expressed as $\mu$ mol. glutamic acid inside the cells of $100 \mathrm{mg}$. yea st. $-x-\times-x-$,

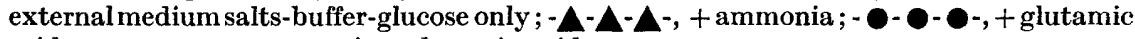
acid; $-0-0-0-,+$ ammonia + glutamic acid.

to that which appears inside the cells (Fig. 4a). When ammonia is added to the suspending medium as ammonium sulphate, the rate at which glutamic 
acid is assimilated from the external medium is decreased, and a correspondingly diminished concentration of glutamic acid is found inside the cells (Fig. 4b).

In considering the importance of glutamic acid assimilation to the yeast cell and the effect which the presence of external supplies of ammonia has on this

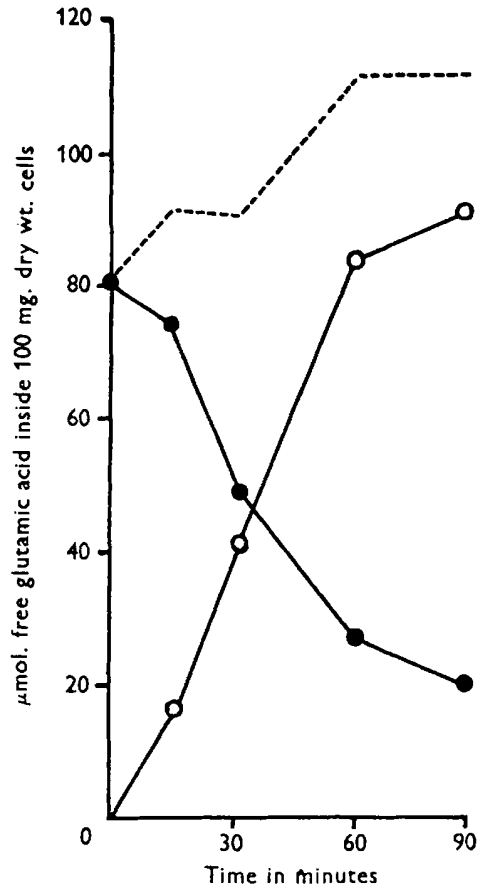

(a)

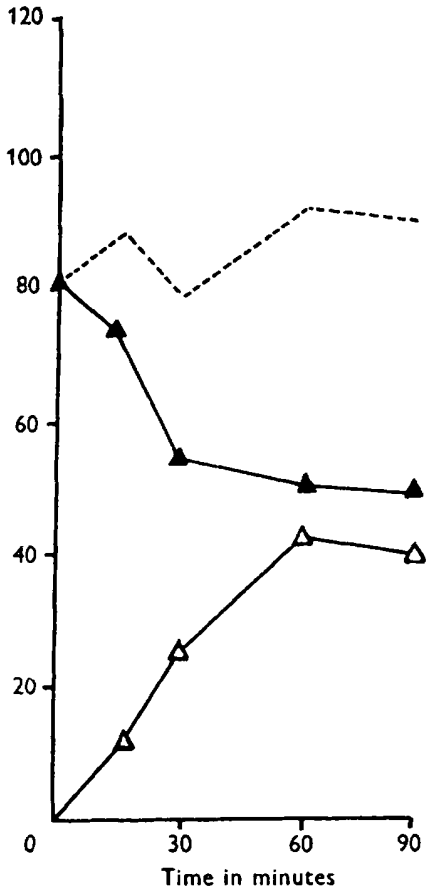

(b)

Fig. 4. Balance between glutamic acid inside the cells of Dutch Top Yeast and in the external medium $(a)$ in ammonia-free salt medium, $(b)$ in the presence of ammonia. Dutch Top Yeast grown for $24 \mathrm{hr}$. at $25^{\circ}$ in medium 1 . Washed suspension of cells dry wt. $5.6 \mathrm{mg} . / \mathrm{ml}$. incubated in buffered salt medium containing $2 \%(\mathrm{w} / \mathrm{v})$ glucose under the following conditions: (a) (1) no additions, (2) $+8.92 \mu \mathrm{mol}$. external glutamic acid $/ \mathrm{ml}$; $(b)(3)+14 \cdot 28 \mu \mathrm{mol}$. $\mathrm{NH}_{3}-\mathrm{N} / \mathrm{ml}$., (4) $+8 \cdot 92 \mu \mathrm{mol}$. glutamic acid and $14 \cdot 28 \mu \mathrm{mol}$. $\mathrm{NH}_{3}-\mathrm{N} / \mathrm{ml}$. Samples withdrawn at intervals, yeast centrifuged down, washed, and the glutamic acid content of the cells and of the supernatant medium in (2) and (4) estimated. - $0-0-0$ - represents the glutamic acid content of the cells in the presence of external supplies of glutamic acid, estimated by the difference between free glutamic acid content of the cells in (1) and (2) and again between (3) and (4) when ammonia is also present in the external medium. Results are expressed as $\mu$ mol. glutamic acid inside $100 \mathrm{mg}$. dry wt. of cells. - - - - represents the amount of glutamic acid disappearing from the external medium measured in (2) and (4), expressed as $\mu$ mol. glutamic acid taken up by $100 \mathrm{mg}$. dry wt. of cells. ....-- represents the total free amino-acid present, glutamic acid disappearing from external medium + increase in free glutamic acid content of the cells.

process, it will be remembered that when growth takes place in a medium devoid of amino-acids, free amino-acids are still to be found inside the cells; the yeast must be able to synthesize all its amino-acid requirements from the ammonium salt. Fig. 3 shows that synthesis of glutamic acid takes place under these conditions. The concentration of glutamic acid diminishes when the cells 
are incubated in the presence of glucose only, but if an ammonium salt is also present the concentration is maintained, and increases slightly. When the cells are incubated with glutamic acid, ammonia decreases the concentration of free glutamic acid inside the cells. It has been shown that the cells can synthesize glutamic acid from ammonium salts in the presence of glucose, and

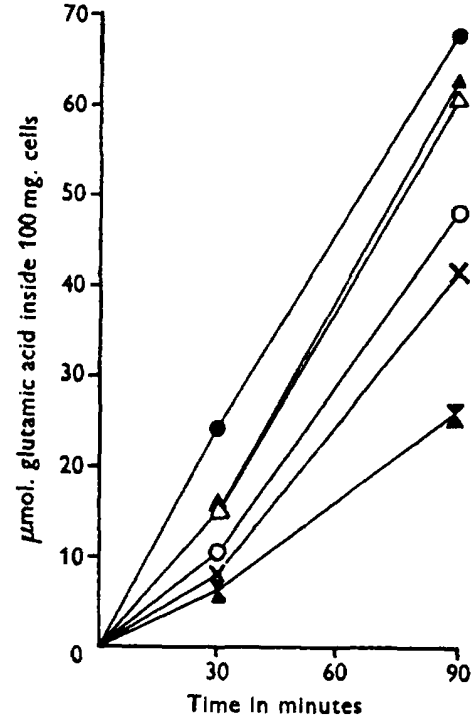

Fig. 5

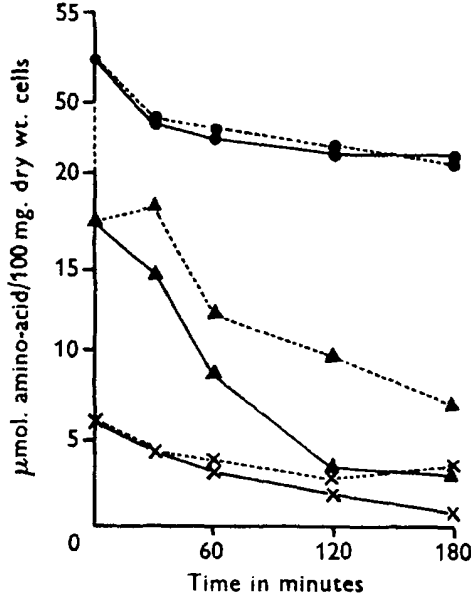

Fig. 6

Fig. 5. Effect of ammonia and certain amino-acids in decreasing the rate of glutamic acid assimilation by yeast. Dutch Top Yeast grown for $24 \mathrm{hr}$. at $25^{\circ}$ in medium 1 . Washed suspension of cells incubated in buffered salt medium at $\mathrm{pH} 4.5$ containing $3.0 \%(\mathrm{w} / \mathrm{v})$ glucose and $8.98 \mu \mathrm{mol}$. glutamic acid and $8.2 \mathrm{mg}$. dry wt. yeast/ml., with further additions: - - - - -, no additions; $-0-\mathrm{O}-\mathrm{O}-,+14 \cdot 28 \mu \mathrm{mol}$. $\mathrm{NH}_{3}-\mathrm{N} / \mathrm{ml}$; $-\times-\times-\times$,

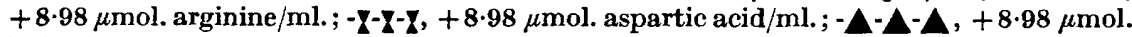
lysine $/ \mathrm{ml}$.; $-\triangle-\triangle-\triangle-,+8.98 \mu \mathrm{mol}$. tyrosine $/ \mathrm{ml}$. Results expressed as $\mu$ mol. glutamic acid appearing inside $100 \mathrm{mg}$. dry wt. of cells.

Fig. 6. Loss of amino-acids from the cells of Dutch Top Yeast in the presence of glucose and ammonia. Dutch Top Yeast grown for $24 \mathrm{hr}$. at $25^{\circ}$ in medium 1 . Washed suspension of cells incubated at $25^{\circ}$ in buffered salt medium at $\mathrm{pH} 4.5$ containing $4 \%(\mathrm{w} / \mathrm{v})$ glucose and 6.0 mg. dry wt. yeast/ml. Ammonia concentration $7 \cdot 14 \mu \mathrm{mol}$. $\mathrm{NH}_{3}-\mathrm{N} / \mathrm{ml}$. Samples withdrawn at intervals and the free amino-acid content of the cells estimated. medium; - - - - -, lysine content/100 mg. dry wt. cells; $-\mathbf{\Delta}-\mathbf{\Delta}-\mathbf{A}-$, glutamic acid content/100 mg. dry wt. cells; $-x-x-x-$, arginine content $/ 100 \mathrm{mg}$. dry wt. cells.

it might be that the decreased assimilation in the presence of ammonia is the resultant of some sort of balance between assimilatory and synthetic processes; but other evidence, shortly to be published, rules out this possibility.

The effect in decreasing the rate of glutamic acid assimilation is not specific to ammonia. Fig. 5 shows that, whereas lysine and tyrosine have little effect on the uptake of glutamic acid, both arginine and aspartic acid have a greater sparing action on glutamic acid assimilation than ammonia itself. When these results are compared with the growth experiments of Thorne (1945) a definite 
relationship is found. Aspartic acid is a better source of nitrogen for growth than glutamic acid or ammonia, and aspartic acid exerts a greater sparing action on the assimilation of glutamic acid than does ammonia itself. Lysine, on the other hand, which is virtually unattacked by yeast, has no significant sparing action.

Further evidence in support of this view was obtained by studying the concentrations of various amino-acids inside cells incubated with glucose both in the presence and absence of ammonia, as shown in Fig. 6. The high initial concentration of internal lysine does not decrease significantly over the incubation period, even in the absence of ammonia, and lysine consequently cannot be undergoing any metabolism; whereas the concentrations of both arginine and glutamic acid decrease as these compounds are metabolized, and ammonia exerts a definite sparing action in both cases.

\section{DISCUSSION}

The present work shows that yeast contains the six amino-acids arginine, glutamic acid, histidine, lysine, ornithine and tyrosine in the free state inside the cell. This is so even when growth takes place in a medium free from aminoacids. When the sole source of nitrogen is an ammonium salt, synthesis of amino-acids must therefore take place inside the cell. By growing the organisms in a medium rich in free amino-acids, however, the concentration of amino-acids within the cell is increased, and from the effect of external glutamic acid on its concentration within the cell, it is clear that under conditions which exist in a medium containing amino-acids, this amino-acid is taken up from the external environment. Such assimilation will account for the higher values found for the amino-acid content of the yeast grown in a medium rich in amino-acid. For the assimilation, a source of energy, such as is provided by the simultaneous metabolism of glucose, is essential; and similarly glucose is necessary for the utilization of glutamic acid within the cell.

When cells rich in free amino-acids are suspended in salt media not containing amino-acids, there is no decrease in the internal concentration of glutamic acid until a source of energy is provided, when it begins to decrease steadily. This decrease could be accounted for in several ways, either by outward diffusion of the amino-acid or by its condensation into combined glutamic acid in peptide or protein, but the evidence rules out these possibilities. The glutamic acid which disappears may therefore be metabolized in some other way, and its utilization by the growing cell as the sole nitrogen source indicates that it can be converted into other amino-acids and nitrogenous compounds. It may be deaminated as the first step in such intracellular reactions and such a hypothesis is supported by the relationship between the effect of ammonia and other amino-acids in decreasing the rate at which glutamic acid is taken up from the external medium. Thorne (1939) suggested that the chief differences between the various amino-acids as effective sources of nitrogen for growth may be largely due to the ease with which yeast is able 
to deaminate them; the present data on the effect of ammonia and various amino-acids on glutamic acid assimilation are not inconsistent with this suggestion.

The concentration of free amino-acids found inside the cell represents a balance between the rate at which they are utilized and the rate at which they are synthesized or taken up from the external medium (Gale \& Mitchell, 1947). Consequently the appearance of free amino-acids inside a cell must mean that the amino-acids are either synthesized or taken from the medium at a rate greater than that at which they can be metabolized within the cell. This appears to be the case with glutamic acid in the yeast cell even when growing in medium free from amino-acids. The fact that the presence of ammonia decreases the concentration of free glutamic acid within the cell indicates that ammonia may $(a)$ decrease the rate of glutamic acid uptake, $(b)$ increase the rate of its internal metabolism, or $(c)$ exert both effects. Possibility $(b)$ is ruled out by the facts presented in Fig. 4. If ammonia and ammonia precursors act by 'sparing' glutamic acid, as shown by Fig. 4, then the primary action of ammonia must be on assimilation.

I wish to record my indebtedness to the late Dr Marjory Stephenson, F.R.S. and to thank Dr E. F. Gale for the help and encouragement they gave me throughout the course of this work. I am also indebted to the Medical Research Council for a personal grant.

\section{REFERENCES}

Conway, E. J. \& Byrne, A. (1933). An adsorption apparatus for the micro-determination of certain volatile substances. 1 . The micro-determination of ammonia. Biochem. J. 27, 419.

Ehrlich, F. (1907). Ceber die Bedingungen der Fuselolbildung und über ihren Zusammenhang mit dem Eiweissaufbau der Hefe. Ber. dtsch. chem. Ges. 40, 1027.

Ehrlich, F. (1909). Ueber die Enstehung der Bernsteinsaure bei der alkoholischen Gärung. Biochem. Z. 22, 391.

Freeland, J. \& Gale, E. F. (1947). The amino-acid composition of certain bacteria and yeasts. Biochem. J. 41, 135.

Gale, E. F. (1945). Studies on bacterial amino-acid decarboxylases. 5. The use of specific decarboxylase preparations in the estimation of amino-acids and in protein analysis. Biochem. $J .39,46$.

GaLE, E. F. (1946). Estimation of $1(+)$-arginine in protein hydrolysates by the use of 1(+)-arginine decarboxylase. Nature, Lond., 157, 265.

Gale, E. F. (1947). The assimilation of amino-acids by bacteria. 1. The passage of certain amino-acids across the cell wall and their concentration in the internal environment of Streptococcus faecalis. J. gen. Microbiol. 1, 53.

Gale, E. F. \& Mrtchell, P. D. (1947). The assimilation of amino-acids by bacteria. 4. The action of triphenylmethane dyes on glutamic acid assimilation. J.gen. Microbiol. 1, 299.

Nielsen, N. \& Hartelius, V. (1938). Wuchsstoffwirkung der Aminosauren. 1. Untersuchungen über die Wuchstoffwirkung der Aminosauren gegenüber Hefe. C.R. trav. Lab. Carlsberg, Ser. physiol. 22, 249.

Stepilenson, M. (1936). Bacterial Metabolism. London: Longmans, Green and Co. Stickland, L. H. (1934). Studies in the metabolism of the strict anaerobes. 1. The chemical reactions by which $\mathrm{Cl}$. sporogenes obtains its energy. Biochem. J. 34, 1746 . 
Stokes, J. L. \& Gunness, M. (1946). The amino-acid composition of micro-organisms. J. Bact. 52, 195.

'TAYLOR, E. S. (1947). The assimilation of amino-acids by bacteria. 3. Concentration of free amino-acids in the internal environment of various bacteria and yeasts. J. gen. Microbiol. $1,86$.

Thorve, R. S. W. (1937). The assimilation of nitrogen from amino-acids by yeast. J. Inst. Brew. 34, 288.

Thorne, R. S. W. (1939). The influence of amino-acid degradation products and some related substances upon yeast growth and fermentation. J. Inst. Brew. $36,14$.

ThorNe, R. S. W. (1945). Recent work on the nitrogen nutrition of yeast. J. Inst. Brew. 42, 114. 